\title{
The Challenges of Treating a Fused Tooth
}

\author{
Flares BARATTO-FILHO ${ }^{1,2}$ \\ Denise Piotto LEONARDI ${ }^{1}$ \\ Bruno Monguilhott CROZETA ${ }^{1}$ \\ Samantha Pugsley BARATTO ${ }^{1}$ \\ Edson Alves CAMPOS ${ }^{3}$ \\ Flavia Sens Fagundes TOMAZINHO ${ }^{1}$ \\ Tatiana Miranda DELIBERADOR ${ }^{1}$ \\ ${ }^{1}$ Positivo University, Curitiba, PR, Brazil \\ ${ }^{2}$ Univille, Curitiba, PR, Brazil \\ ${ }^{3}$ Araraquara Dental School, UNESP - Univ Estadual Paulista, Araraquara, SP, Brazil
}

\begin{abstract}
This paper describes and discusses the multidisciplinary treatment involving a permanent maxillary lateral incisor fused to a supernumerary tooth, both presenting pulp necrosis and periapical lesion. A 15-year-old male patient sought treatment complaining of pain, swelling and mobility on the maxillary right lateral incisor. After clinical and radiographic examination, root canal preparation was performed according to the crown-down technique and a calcium hydroxide dressing was placed for 15 days. The patient returned and the definitive endodontic filling was done with thermomechanical compaction of gutta-percha and sealer. After 18 months, clinical and radiographic examinations were carried out and no pain or swelling was reported. Two years after endodontic treatment, the patient returned for periodontal and cosmetic treatments. Nine months later, a cone-beam computed tomography (CBCT) revealed that the previously detected periodontal defect and periapical lesion were persistent. Apical endodontic surgery was indicated. The supernumerary tooth was removed, the communicating distal surface was filled and the surgical site received bioactive glass and demineralized bovine organic bone. The pathological tissue was submitted to histopathological examination and the diagnosis was periapical cyst. One year after the apical endodontic surgery, CBCT showed bone formation at maxillary lateral incisor apical area. Two years after the surgery, the restoration was replaced due to aesthetic reasons and periapical radiograph showed success after 5 years of treatment. A correct diagnosis and establishment of an adequate treatment plan resulted in a successful management of the case.
\end{abstract}

Key Words: Fusion, apical surgery, cone-beam computed tomography, supernumerary tooth.

\section{INTRODUCTION}

Knowledge of internal morphology of human teeth is essential for the success of endodontic treatment. Just as important is the identification of the possible anatomic variations and different anomalies present in all tooth groups. One of these anomalies causing major difficulties for diagnosis and treatment is tooth fusion, which may be commonly confused with tooth germination. Both anomalies originate in tooth development and cause alteration in the number and shape of the affected teeth (1).

Tooth gemination is an anomaly where two teeth attempt to develop from a single tooth bud, but without complete separation, thus resulting in a larger tooth than normal but without alterations in the number of teeth in the affected dentition (2). The geminated tooth may present two crowns, together or separate, sharing a single root canal (3).

Fusion, unlike gemination, occurs due to the union of two or more separately developing tooth buds at dentinal level, presenting one single large tooth structure and an increase in tooth number of the affected dentition, especially when it takes place between normal and supernumerary teeth $(2,3)$. Fusion etiology is uncertain and may be associated to genetic predisposition, racial differences and impact and/or trauma during tooth bud development (4).

Clinically, several complications may occur due to fusion of teeth, namely caries in the groove between

Correspondence: Prof. Dr. Flares Baratto-Filho, Rua Professor Pedro Viriato Parigot de Souza, 5300, Campo Comprido, $81200-100$ Curitiba, PR, Brasil. e-mail: fbaratto1@gmail.com 
the fused crowns leading to endodontic treatment, if not treated; tooth impaction, diastemas, aesthetic and periodontal problems, which often demand a multidisciplinary treatment $(5,6)$.

This paper describes a complex case of a permanent maxillary lateral incisor fused to a supernumerary tooth, in which a series of multidisciplinary treatments were performed after endodontic therapy.

\section{CASE REPORT}

A 15-year-old male patient was referred to Positivo University complaining of pain, swelling and mobility on the maxillary right lateral incisor (MRLI) (Fig. 1A). After clinical and radiographic examinations, a fusion between maxillary lateral incisor and a supernumerary tooth (Fig. 1B-F) was diagnosed. Sensitivity test (Endofrost; Roeko, Langenau, Germany) showed a negative response with a suggestion of periapical cyst. The root canal was prepared using Profile rotary system (Dentsply Maillefer, Ballaigues, Switzerland) according to the crown-down technique was performed. During preparation, $2.5 \%$ sodium hypochlorite and $17 \%$ EDTA solutions were used as irrigants. A calcium hydroxide dressing was placed for 15 days.

The patient returned after this time. Swelling and painful symptomatology had disappeared, and so definitive endodontic filling was performed with thermomechanical compaction of the gutta-percha using Gutta Condensor (Dentsply Maillefer) and AH-plus sealer (Dentsply Maillefer) (Fig. 1G).

After 18 months, clinical and radiographic examinations were carried out and no pain or swelling were reported (Fig. 1H). During the clinical examination, the endodontist observed that the supernumerary tooth crown had been removed by another dentist, in an attempt of cosmetic treatment.

Two years after endodontic treatment, the patient returned to the University for periodontal and cosmetic treatment, now with an orthodontic treatment initiated (Fig. 2A). Periodontal surgery and root planing were performed and the supernumerary tooth was restored. A periapical radiograph was taken (Fig. 2B-F).

Nine months later, a cone beam computed tomography (CBCT) scan (Fig. 3) showed that the periodontal defect and periapical lesion persisted. At this moment, an apical endodontic surgery was indicated and planned.

After the root-end resection, the supernumerary tooth was removed and the communicating distal surface was filled with white mineral trioxide aggregate (Ângelus-MTA, Londrina, PR, Brazil) (Fig. 4F). The root-end cavity was filled with the same material while the surgical site received bioactive glass (Biogran; Biomet 3i, Palm Beach Gardens, FL, USA) (Fig. 4G) followed by a layer of demineralized bovine organic
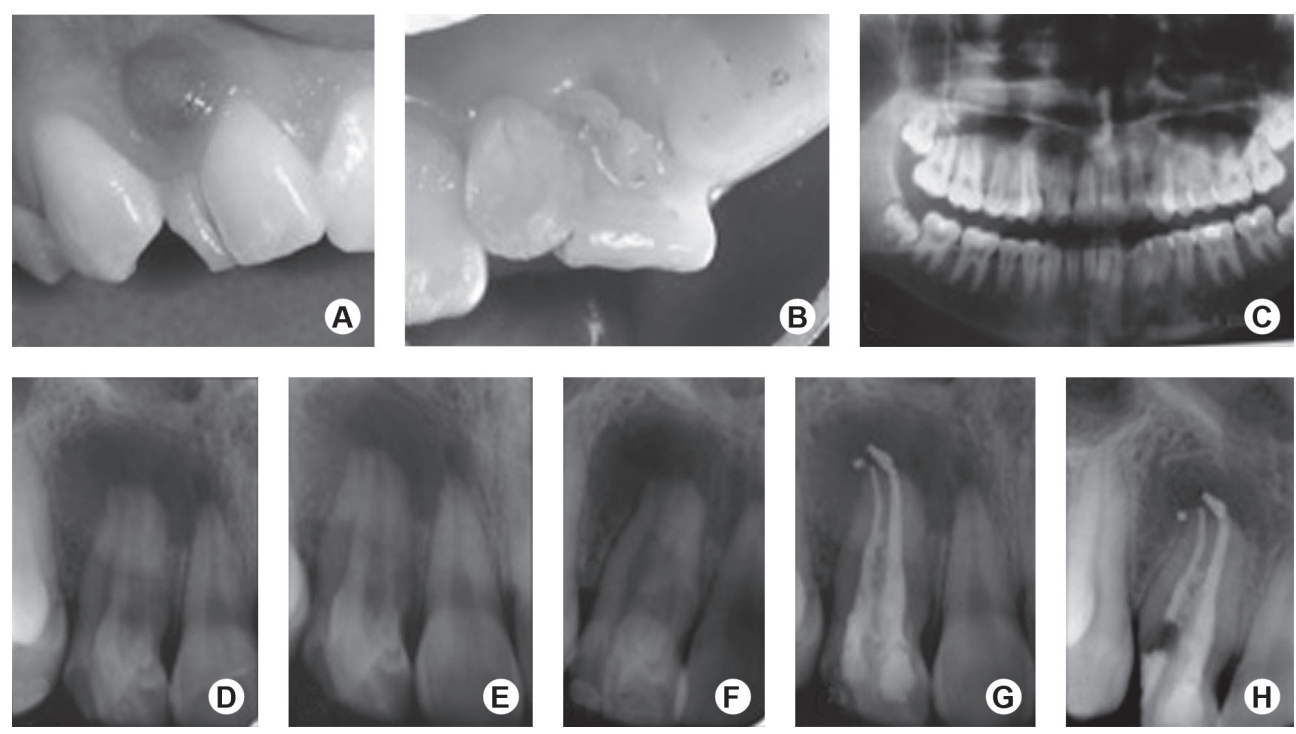

Figure 1. Endodontic treatment. A: initial aspect when patient first sought treatment; Fusion of the MRLI with the supernumerary tooth and swelling; B: palatal surface of fused teeth; C: panoramic radiograph for diagnostic purposes; D, E and F: mesio-, ortho-, and distoradial periapical radiographs, respectively, showing total fusion of the MRLI with the supernumerary tooth; G: final radiograph after root canal filling; H: 18-month follow-up radiograph after endodontic treatment. 
bone (GenOx Org Cortical; Baumer, Mogi Mirim, SP, Brazil) (Fig. 4H) over it. The pathological tissue was removed and submitted to histopathological examination and the diagnosis was periapical cyst (Fig. 5).

One year after the apical endodontic surgery, CBCT showed bone formation at maxillary lateral incisor apical area (Fig. 6). Two years after the surgery, the restoration was repalced (Fig. 7A and B) due to aesthetic reasons. A periapical radiograph (Fig. 7C) and CBCT scan (Fig. 8) showed success of the treatment (5 year after treatment).

\section{DISCUSSION}

Tooth fusion in the permanent dentition is less frequent than in the primary dentition, occurring particularly in incisors and canines (7). The incidence of fusion in permanent supernumerary teeth is $0.1 \%$ and it generally involves maxillary anterior teeth, just as the case presented here (8). Unilateral incidence is about $0.5 \%$ in primary dentition and $0.1 \%$ in permanent dentition $(7,9)$.

Fusion must be distinguished from tooth
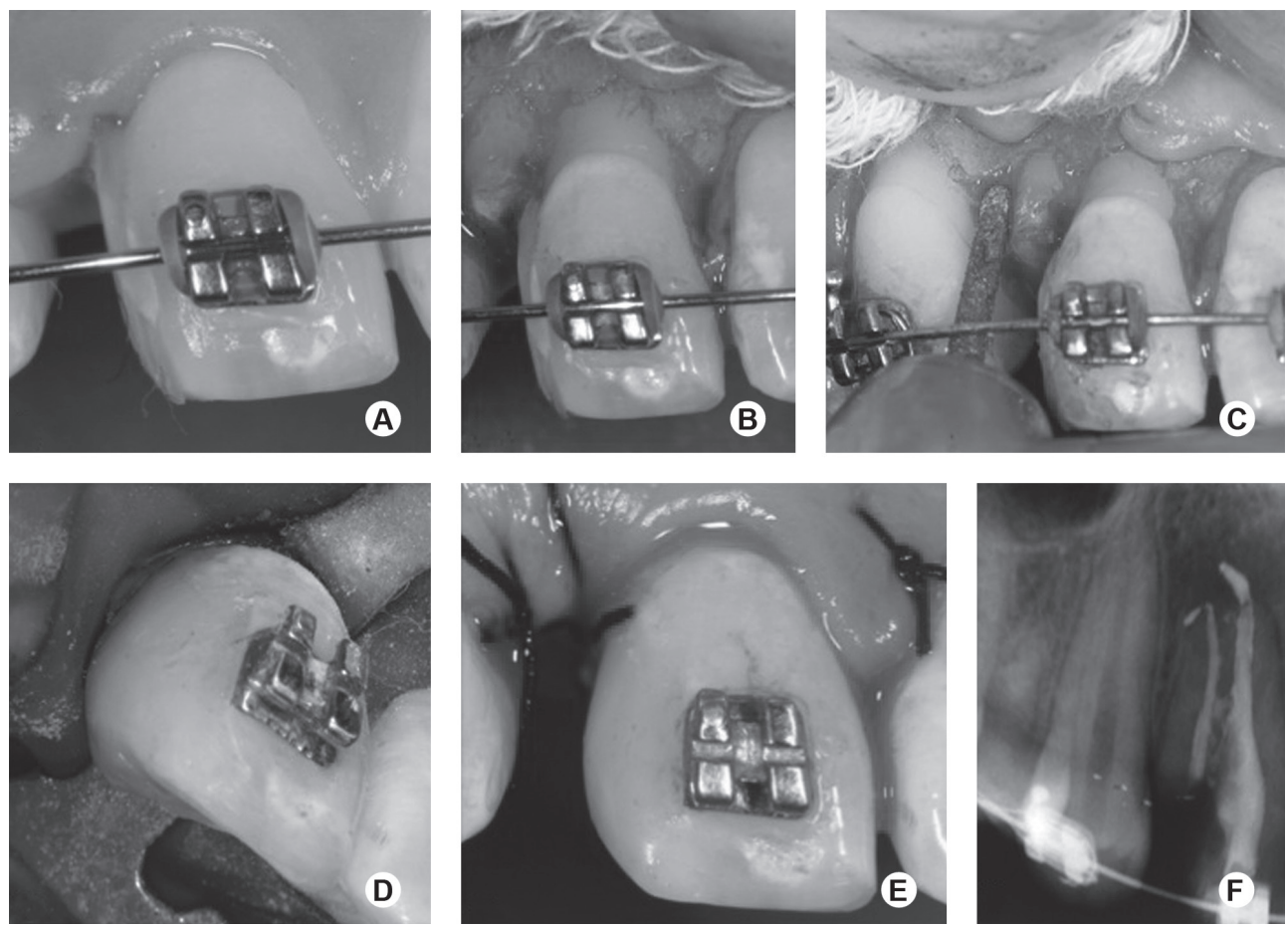

Figure 2. Periodontal surgery and coronal restoration, 2 years after initial treatment. A: MLI crown aspect and supernumerary crown sectioned by a previous cosmetic treatment; B: after flap raising; C: diamond bur for supernumerary root weariness and planing; D: MRLI with rubber dam isolation after composite resin restoration; E: after suture; F: post-surgery radiograph showing supernumerary root remnant.
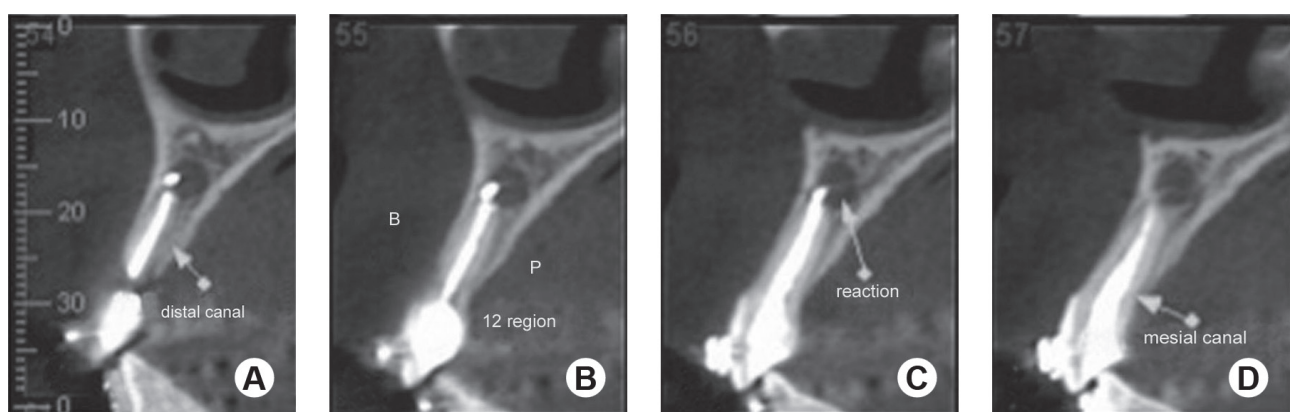

Figure 3. CBCT scans A: distal root canal (arrow); B: MRLI area; C: periapical lesion (arrow); D: mesial root canal (arrow). 
gemination. In this case report, two distinct root canals were observed, both clinically and radiographically. Therefore, an accurate clinical and radiographic examination combined with knowledge of the endodontic features of this anatomic situation is necessary to perform the diagnosis (10). CBCT scans and an operative microscope may help the diagnosis and facilitate root canal localization in cases of complex and varied morphology. In the present case, CBCT was performed to have a more detailed view of the complex root canal system morphology since CBCT enables threedimensional image reconstruction (11).

Case reports have described the multidisciplinary treatment of fused permanent teeth, comprising extraction, endodontic treatment, tooth mesiodistal dimension reduction followed by orthodontic treatment, tooth hemisection, and intentional replantation $(7,12)$. In this case, endodontic treatment was performed and an apical surgery was necessary.

Endodontic treatment of fused teeth may be a challenge, since localization and access to the canals might pose additional difficulties (3). Internal morphology of fused teeth varies and pulp chambers may be together or separated and a radicular area can be found (13). Although the communication between pulp chambers of fused teeth is common (14) and despite its presence in this case, the access was distinct to preserve the tooth structure.

Inappropriate root canal cleaning and shaping of a fused tooth plays an important role in endodontic treatment failure, due to presence of root canals with different morphologies $(9,15-17)$. Therefore, endodontic failure might occur, even with the use of calcium hydroxide dressing.

Periapical cysts develop from either granulomas or proliferation of epithelial rests of Malassez (18). The frequency of periapical cyst ranges from 6 to $55 \%$. This

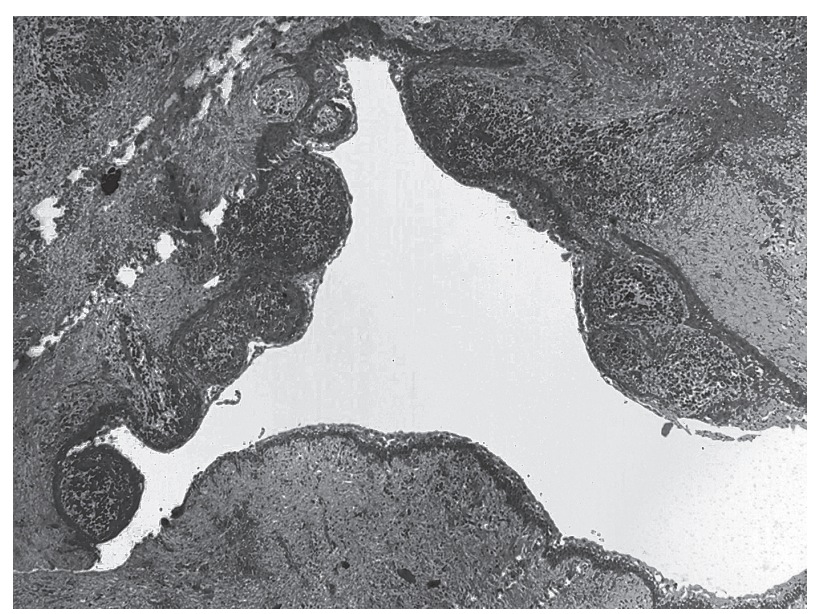

Figure 5. Histopathological examination of the tissue removed from periapical region, with diagnosis of periapical cyst.
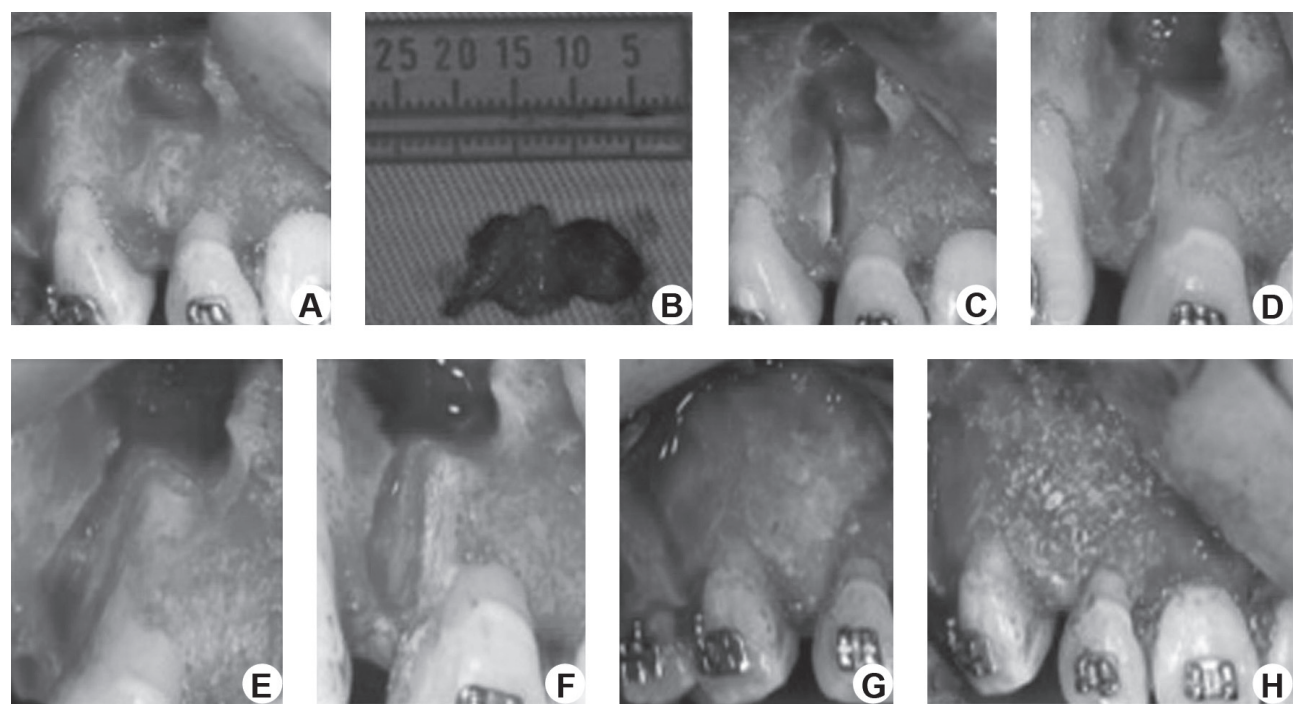

Figure 4. Periapical endodontic surgery (33 months after initial treatment). A: surgical site after periapical lesion removal; B: pathological tissue removed from periapical area; C: supernumerary tooth sectioning; D: MRLI root distal surface showing exposed filling material after supernumerary root hemisection; E: MRLI root distal surface after groove on the exposed filling material; F: MTA placement on the groove of the MRLI root distal surface and surgical site filling with bioactive glass; H: bone defect filling with demineralized bovine organic bone. 
wide range may be explained by different procedures to collect the sample to assess the characteristics of the periapical lesions or by the existence of different periapical lesion classifications (19).

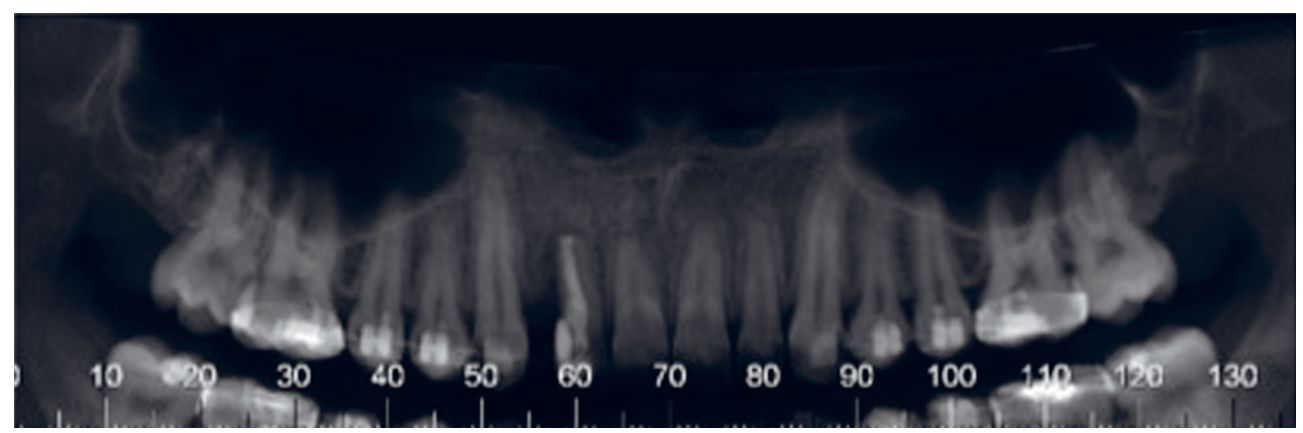

Figure 6. $\mathrm{CBCT}$ at 12 months after apical endodontic surgery displaying apical bone formation at MRLI area.
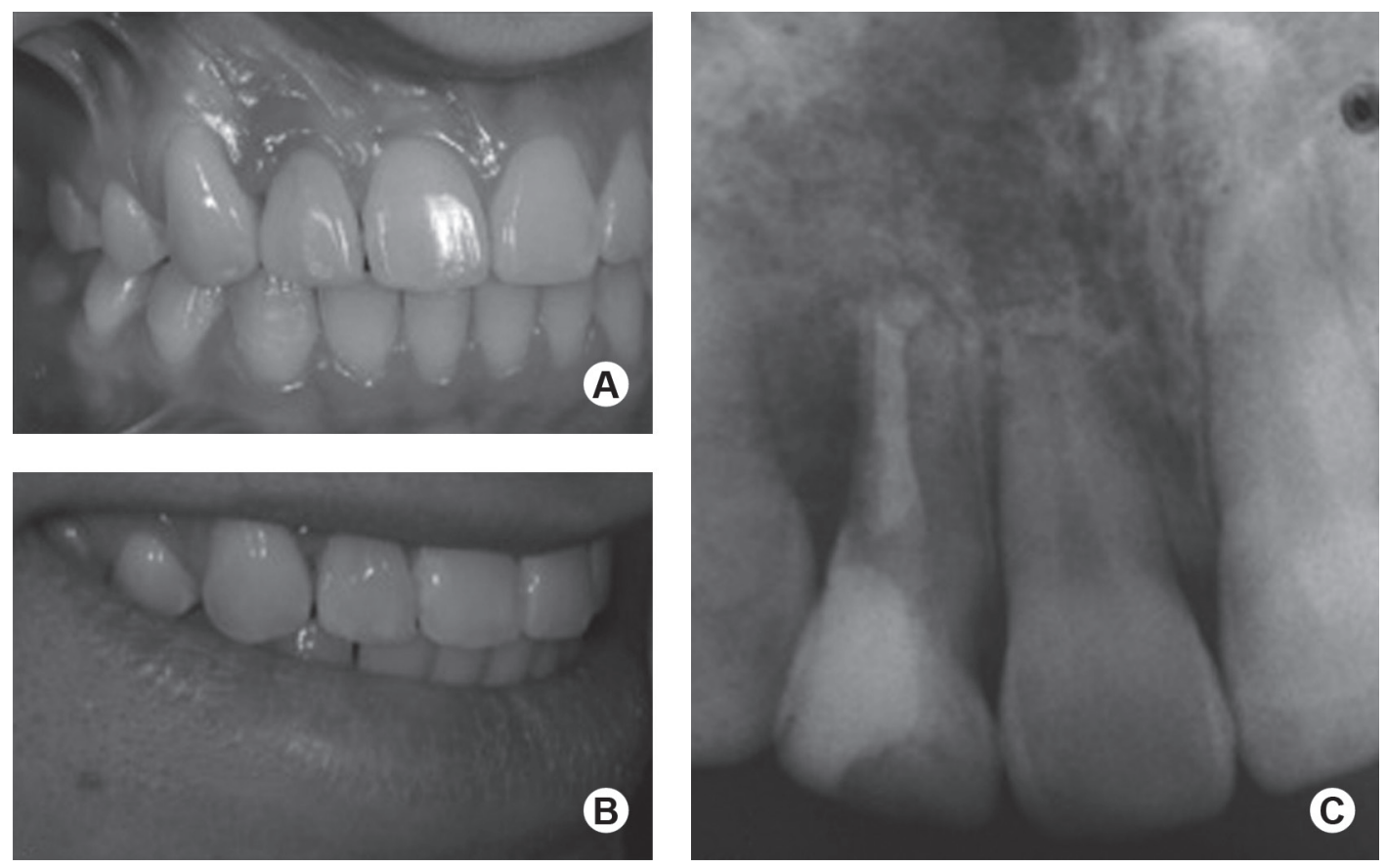

Figure 7. Aesthetic restoration (5 years after initial treatment). A and B: final aspect after aesthetic restoration; C: follow-up periapical radiograph showing bone formation at MRLI apical area.

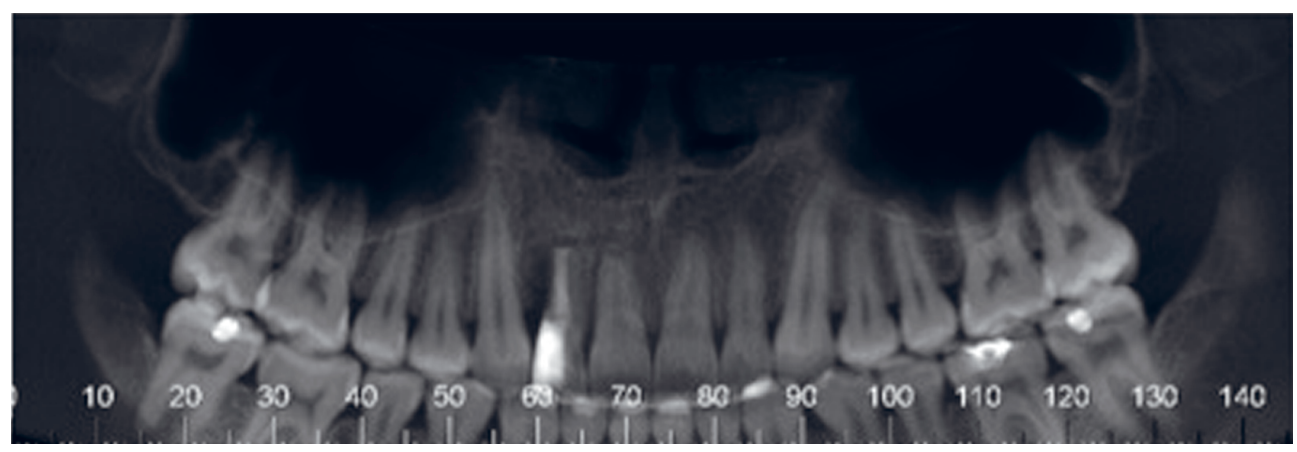

Figure 8. CBCT scam taken 2 years after apical endodontic surgery showing bone formation and disappearance of the periapical lesion. 
The literature has recommended tooth hemisection for fusion cases, justifying its choice in this case $(16,17)$. In order to avoid cracks on root apical surface in this case, the apex cutting level was $45^{\circ}$ toward labial direction and the root-end cavity was prepared using a low-speed handpiece. Apical root planing was done with multifluted burs because it must present a plane and smooth aspect, without degrees or irregularities that could act as irritants and stimulate root dentin resorption during periapical healing. This planing procedure also closes the open dentinal tubules, decreasing apical leakage (20). The root-end cavity was prepared and filled with MTA because it is a biocompatible material and allows the proliferation of periodontal ligament cells, as well as promotion of an adequate sealing (21-23).

The surgical site was filled with bioactive glass, because of its osteoinductive properties, followed by the placement of demineralized bovine organic bone on its top and within the bone defect at the labial surface to allow bone repair (24). Demineralized bovine organic bone prevents contamination and lesion relapse via periodontium (25).

Anatomic variations should be carefully observed and considered during the diagnosis and treatment planning of teeth with anomalies in order to enhance the chances of success. The case reported in this paper confirms the need of accurate planning and of a multidisciplinary approach when dealing with cases of tooth fusion.

\section{RESUMO}

Este caso descreve o tratamento multidisciplinar de um incisivo lateral superior permanente fusionado a um dente supranumerário, ambos apresentando necrose pulpar e lesão periapical. Paciente compareceu ao consultório se queixando de dor, edema e mobilidade do incisivo lateral superior. O preparo endodôntico foi realizado no sentido coroa-ápice e foi colocada pasta de hidróxido de cálcio como medicação intra-canal por 15 dias. A seguir, a obturação foi realizada pela termoplastificação da guta-percha. Após 18 meses, foram realizados exames clínicos e radiográficos indicando ausência de dor e edema. Dois anos após o tratamento endodôntico, o paciente retornou para o tratamento periodontal e estético. Nove meses depois, foi realizada tomografia computadorizada e observou-se presença de defeito periodontal e lesão periapical. Foi então indicada e planejada a cirurgia paraendodôntica. $\mathrm{O}$ dente supranumerário foi removido e a área de comunicação com o canal radicular do incisivo lateral foi preenchida; a loja cirúrgica foi preenchida com vidro bioativo e osso orgânico bovino desmineralizado. $\mathrm{O}$ tecido patológico da lesão periapical foi submetido à análise histopatológica sendo diagnosticado como cisto periapical. Um ano após a cirurgia parendodôntica, uma nova tomografia computadorizada mostrou neoformação óssea na região periapical do dente em questão. Doi anos após a cirurgia, a restauração foi trocada devido à motivos estéticos e uma radiografia periapical mostrou sucesso do tratamento (5 anos após o tratamento inicial). Um correto diagnóstico e plano de tratamento multidisciplinar é essencial para o sucesso do tratamento de dentes fusionados à dentes supranumerários.

\section{REFERENCES}

1. Ghoddusi J, Zarei M, Jafarzadeh H. Endodontic treatment of a supernumerary tooth fused to a mandibular second molar: a case report. J Oral Sci 2006;48:39-41.

2. Pereira AJ, Fidel RA, Fidel SR. Maxillary lateral incisor with two root canals: fusion, gemination or dens invaginatus? Braz Dent $\mathrm{J}$ 2000;11:141-146.

3. Kremeier K, Pontius O, Klaiber B, Hülsmann M. Nonsurgical endodontic management of a double tooth: a case report. Int Endod J 2007;40:908-915.

4. Kaffe I, Littner MM, Begleiter A, Buchner A. Fusion of permanent molars. Quintessence Int Dent Dig 1982;13:1237-1239.

5. Clem WH, Natkin E. Treatment of fused tooth: report of a case. Oral Surg Oral Med Oral Pathol 1996;21:365-370.

6. Atasu M, Cimilli H. Fusion of the permanent maxillary right incisor to a supernumerary tooth in association with a gemination of permanent maxillary left central incisor: a dental, genetic and dermatologic study. J Clin Pediatr Dent 2000;24:329-333.

7. Sivolella S, Bressan E, Mirabal V, Stellini E, Berengo M. Extraoral endodontic treatment, odontotomy and intentional replantation of a double maxillary lateral permanent incisor: case report and 6-year follow-up. Int Endod J 2008;41:538-546.

8. Nunes E, de Moraes IG, Novaes PMO, de Sousa SMG. Bilateral fusion of mandibular second molars with supernumerary teeth: case report. Braz Dent J 2002;13:137-141.

9. Kim E, Jou Y. A supernumerary tooth fused to the facial surface of a maxillary permanent central incisor: case report. J Endod 2000;26:45-48.

10. Lyroudia K, Mikrogeorgis G, Nikopoulos N, Samakovitis G, Molyvdas I, Pitas I. Computerized 3-D reconstruction of two 'double teeth'. Endod Dent Traumatol 1997;13:218-222.

11. Baratto Filho F, Zaitter S, Haragushiku GA, de Campos EA, Abuabara A, Correr GM. Analysis of the internal anatomy of maxillary first molars by using different methods. J Endod 2009;35:337-342.

12. Mancuso A. The treatment of fusion and supernumerary maxillary central incisors: a case report. Gen Dent 2003;51:343-345.

13. Rani AK, Metgud S, Yakub SS, Pai U, Toshniwal NG, Bawaskar N. Endodontic and esthetic management of maxillary lateral incisor fused to a supernumerary tooth associated with a talon cusp by using spiral computed tomography as a diagnostic aid: a case report. J Endod 2010;36:345-349.

14. Tsesis I, Steinbock N, Rosenberg E, Kaufman AY. Endodontic treatment of developmental anomalies in posterior teeth: treatment of geminated/ fused teeth: a report of two cases. Int Endod J 2003;36:372-379.

15. Indra R, Srinivasan MR, Farzana H, Karthikeyan K. Endodontic management of a fused maxillary lateral incisor with a supernumerary tooth: a case report. J Endod 2006;32:1217-1219.

16. Karacay S, Guven G, Koymen R. Management of a fused central incisor in association with a macrodont lateral incisor: a case report. Pediatr Dent 2006;28:336-340.

17. Hulsmann M, Bahr R, Grohmann U. Hemisection and vital treatment of a fused tooth - literature review and case report. 
Endod Dent Traumatol 1997;13:253-258.

18. Lin LM, Huang GT, Rosenberg PA. Proliferation of epithelial cell rests, formation of apical cysts, and regression of apical cysts after periapical wound healing. J Endod 2007;33:908-916.

19. Schulz M, von Arx T, Altermatt HJ, Bosshardt D. Histology of periapical lesions obtained during apical surgery. J Endod 2009;35:634-642.

20. Gerhardt OM, Rockenbach BMC, Wehmeyer FP, da Cunha Filho JJ, Puricelli E. Scanning electron microscopy analysis of surfaces after apicoectomy resection with burs and lasers. Chirurgia 2010;23:25-30.

21. Johnson BR. Considerations in the selection of a root-end filling material. Oral Surg Oral Med Oral Pathol Oral Radiol Endod 1999;87:398-404.

22. Samara A, Sarri Y, Stravopodis D, Tzanetakis GN, Kontakiotis EG, Anastasiadou E. A Comparative study of the effects of three root-end filling materials on proliferation and adherence of human periodontal ligament fibroblasts. J Endod 2011;37:865-870.

23. Fernandez YSA, Leco BMI, Martinez GJM. Metaanalysis of filler materials in periapical surgery. Med Oral Patol Oral Cir Bucal 2008;13:e180-e185.

24. Lynch SE, Genco RJ, Marx RE. Tissue engineering: applications in maxillo-facial surgery and Periodontics. Carol Stream: Quintessence Books, 1999.

25. Bernabé PF, Melo LG, Cintra LT, Gomes-Filho JE, Dezan Jr E, Nagata MJ. Bone healing in critical size defects treated with either bone graft, membrane, or a combination of both materials: a histological and histometric study in rat tibiae. Clin Oral Implants Res 2012;23:384-388.

Received March 11, 2012

Accepted April 13, 2012 